\title{
Relationship between male acoustic response and female wingbeat frequency in a chironomid midge, Chironomus yoshimatsui (Diptera: Chironomidae)*
}

\author{
Ken-ichi Ogawa** and Hideki Sato*** \\ ** Department of Immunology and Medical Zoology, St. Marianna University \\ School of Medicine, Kawasaki 216, Japan \\ *** Public Health Institute of Kawasaki City, Kawasaki 210, Japan
}

(Received: June 5, 1993)

Key words: swarm, sound trap, chironomid, wingbeat frequency, acoustic response, air temperature.

\begin{abstract}
The features of acoustic response and wingbeat frequency of a chironomid midge, Chironomus yoshimatsui were studied. The swarms observed were formed above the ground close by cherry trees. The swarming males were mainly caught by cylindrical sound traps emitting sound frequencies of $180-270 \mathrm{~Hz}$ at between 9 and $15^{\circ} \mathrm{C}$ and of $300-390 \mathrm{~Hz}$ at between 20 and $28^{\circ} \mathrm{C}$ during the experimental period in a field. However, the swarming male responded to a fairly narrow range of sound frequency at an ambient air temperature. Accordingly, there was a good correlation between the air temperature and the sound frequency of the highest male catch. The sound frequency of the highest male catch changed at the rate of $10 \mathrm{~Hz} /{ }^{\circ} \mathrm{C}$. The mean wingbeat frequencies of both sexes were almost at constant levels from the first day of emergence to the 4-day-old after emergence. The male wingbeat frequency was always higher than that of the female at the same air temperature. There was a good correlation between the air temperature and the wingbeat frequency of each adult day in both sexes. The wingbeat frequencies of male and female changed at the rate of $18-21$ and $10-12 \mathrm{~Hz} /{ }^{\circ} \mathrm{C}$, respectively. When the regression line of the female wingbeat frequency on the air temperature of each adult day is compared with that of the sound frequency of the highest male catch on the air temperature, the former is consistent with the latter statistically. This indicates that swarming male has the hearing faculty to be accurately tuned to the wingbeat frequency of conspecific female which is variable with the ambient air temperature.
\end{abstract}

* This study was supported in part by a Grant-inAid of the Kanagawa Academy of Science and Technology, Japan.

** 小川賢一：聖マリアンナ医科大学免疫学・病害動 物学教室（テ216 川崎市宮前区菅生 2-16-1）

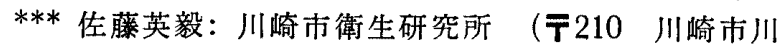
崎区大島 5-13-10)

\section{INTRODUCTION}

In general, males of chironomid species are known to respond and orient to female wingbeat sound (Ikeshoji, 1982). Recently, Ogawa (1992) first reported that the swarm- 
ing males of Rheotanytarsus kyotoensis which broke out in large quantities in an urban area of Tokyo were caught by sound traps emitting artificial sounds. On the other hand, some chironomid species have become nuisances and potent inhalant allergens causing bronchial asthma (Freeman, 1950; Gad El Rab, 1980; Ito et al., 1986; Igarashi et al., 1987; Kino et al., 1987). Especially, Chironomus yoshimatsui is one of the most common nuisances and allergens because of its outbreak in urban areas (Murakami et al., 1986).

For the purpose of developing a new control method of the chironomid adults using their acoustic responses, the present study was carried out to trap adult midges of $C$. yoshimatsui by sounds in a field and measure the wingbeat frequencies of both sexes under various air temperatures and their adult ages.

\section{Materials and Methods}

Study area. The bank of the River Nikaryoyosui ( $c a .5 \mathrm{~m}$ wide) which runs through the town and commercial district of Shukugawara, Kawasaki City was selected as a study area. C. yoshimatsui mainly swarmed close by the trunks or under the branches of cherry trees on the bank.

Adult midge trapping by sounds. The trap used was the cylindrical form used by Ogawa (1992) ; a speaker (9 cm diam.; $1 \mathrm{~W}, 0.7 \Omega$ ) connected to a cassette tape recorder was placed in the center of a cylinder of transparent polyethylene $(c a .9 \mathrm{~cm}$ diam. and $c a$. $66 \mathrm{~cm}$ long). Glue (Kinryu ${ }^{\circledR}$, SDS Biotech K.K., Tokyo) was sprayed on the inside wall of the cylinder. The sticky area was about $900 \mathrm{~cm}^{2}$. Two cylindrical traps, one emitting sound and the other emitting no sound, were set in parallel ca. $30 \mathrm{~cm}$ apart. This sound trap system was placed nearby the swarm during the swarming time before and after dusk during the experimental period from June to December in 1990, 1991 and 1992. Sinusoidal sound of various frequencies recorded from a sound generator on a cassette tape was emitted at intervals 10 -sec on $/ 5$-sec off for $5 \mathrm{~min}$ by a cassette tape recorder. The net number of $C$. yoshimatsui caught by the sound traps was expressed as the catch difference between the sound trap and the without-sound trap. The air temperature was measured just after each trapping $c a .1 \mathrm{~m}$ above the ground in the shade of a cherry tree.

Adult midge sweeping with insect net. Swarming chironomids were collected by random sweeping with a $42-\mathrm{cm}$ diam. insect net during the swarming time and the number of male and female $C$. yoshimatsui caught was counted to study the sex ratio of the swarm population.

Measurement of wingbeat frequency. The larvae of $C$. yoshimatsui collected from the study area in 1992 were reared on ground mouse food at $25^{\circ} \mathrm{C}$, and adults emerged were used in the experiment. The wingbeat frequencies of male and female $C$. yoshimatsui were measured from the first day of emergence to 4-day-old after emergence at $10,15,20$ and $25^{\circ} \mathrm{C}$ by the method of Ogawa (1988); adults were mounted at the ventral side of the abdomen on the tip of a small piece of cardboard with nail polish as adhesive under ether-anesthesia. Flight sounds were recorded with a cassette tape recorder at $c a .1 \mathrm{~cm}$ distance from a microphone when the adult midges started beating their wings. The recorded flight sound was then displayed on an oscilloscope by connecting the earphone outlet to the input of the amplifier and the displayed wave was photographed with a Polaroid ${ }^{\circledR}$ Camera. The wingbeat frequencies of 9 to 17 midges were determined by measuring the wavelengths on the photogram or the oscilloscope directly, and averaged for each experiment.

\section{Results}

\section{Swarm}

Almost all swarms observed were formed from 0.5 to over $5 \mathrm{~m}$ above the ground close by the trunks or under the branches of cherry trees. The swarm was formed in the dusk just after sunset in summer and toward evening in autumn to early winter.

In the present study, 88.6 to $100 \%(98.0 \%$ 
Table 1 Number of male and female $C$. yoshimatsui caught by net sweeping in the swarms.

\begin{tabular}{|c|c|c|c|c|}
\hline \multirow{2}{*}{ Swarm No. } & \multicolumn{3}{|c|}{ Number caught } & \multirow{2}{*}{$\begin{array}{c}\text { Male rate } \\
(\%)\end{array}$} \\
\hline & Male & Female & Total & \\
\hline 1 & 31 & 4 & 35 & 88.6 \\
\hline 2 & 39 & 0 & 39 & 100 \\
\hline 3 & 40 & 0 & 40 & 100 \\
\hline 4 & 66 & 1 & 67 & 98.5 \\
\hline 5 & 69 & 2 & 71 & 97.2 \\
\hline 6 & 78 & 0 & 78 & 100 \\
\hline 7 & 112 & 2 & 114 & 98.2 \\
\hline Total & 435 & 9 & 444 & Average 98.0 \\
\hline
\end{tabular}

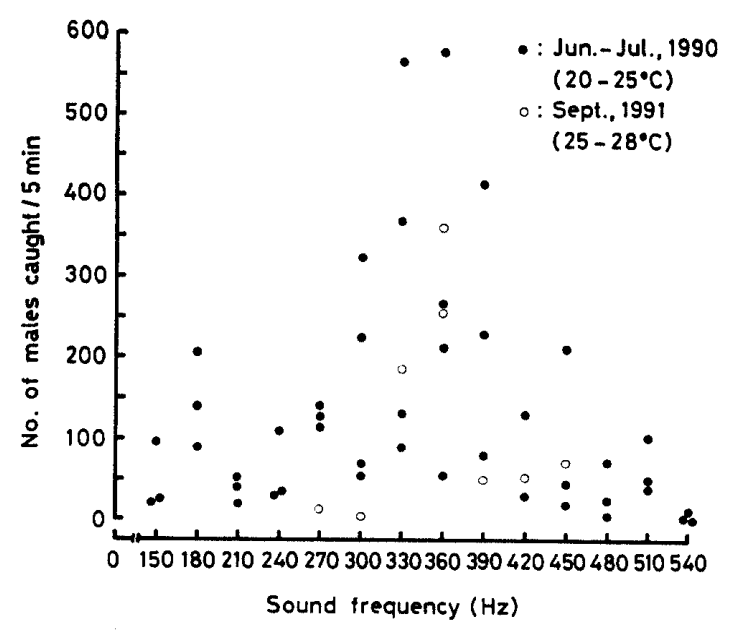

Fig. 1 Number of male C. yoshimatsui caught by a sound trap when sinusoidal sounds of various frequencies were emitted at between 20 and $28^{\circ} \mathrm{C}$ of air temperature $(n=52)$.

in average) of midges caught by net sweeping in the swarm were males (Table 1). Occasionally, a few females were mixed in the swarms.

\section{Sound trapping of males}

The sound traps caught a large number of males when sound frequencies between 180 to $390 \mathrm{~Hz}$ were emitted (Figs. 1 and 2). Specifically, most of the traps caught a lot of males with sound frequencies of 300-390 $\mathrm{Hz}$ at between 20 and $28^{\circ} \mathrm{C}$ of air temperature (Fig. 1). On the other hand, the traps caught few males with the same sound frequencies and above $390 \mathrm{~Hz}$ at between 9 and $15^{\circ} \mathrm{C}$ of air temperature, but most of the traps

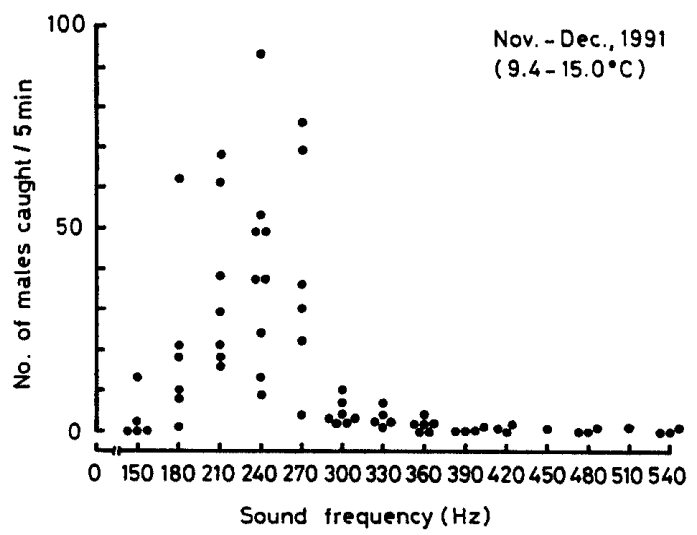

Fig. 2 Number of male $C$. yoshimatsui caught by a sound trap when sinusoidal sounds of various frequencies were emitted at between 9.4 and $15.0^{\circ} \mathrm{C}$ of air temperature $(n=66)$.

caught a lot of males with sound frequencies of $180-270 \mathrm{~Hz}$ (Fig. 2). Furthermore, the sound frequency of the highest male catch changed each day according to the air temperature; a $360-\mathrm{Hz}$ sound trap caught the highest number of 577 males at $23.1^{\circ} \mathrm{C}$ on June 14 in 1990 , a $270-\mathrm{Hz}$ sound trap caught 127 males at $20.0^{\circ} \mathrm{C}$ on June 6 in 1990 and a $240-\mathrm{Hz}$ sound trap caught 93 males at $12.2^{\circ} \mathrm{C}$ on December 5 in 1991 (Fig. 3). Accordingly, the sound frequencies and the air temperature of the days when the highest male catches were made are plotted in Fig. 4. The air temperatures varied between $10.2^{\circ} \mathrm{C}$ on November 27,1991 and $27.0^{\circ} \mathrm{C}$ on September 5, 1991. Figure 4 shows a positive correlation between the sound frequency of the highest male catch and the air tem- 


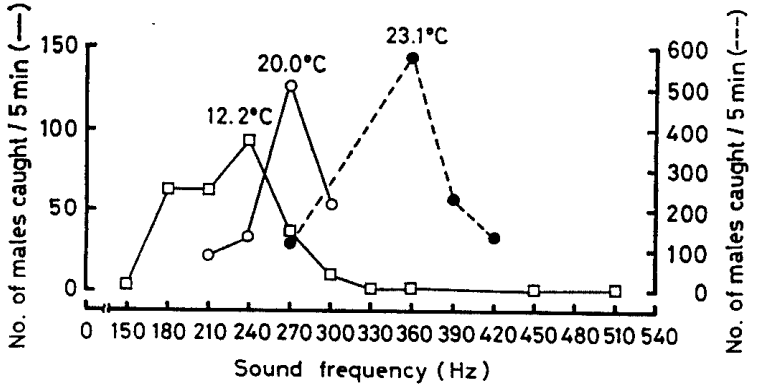

Fig. 3 Patterns of male catches in various sound frequencies each experimental day.

$\bigcirc$, June 6, 1990; ○, June 14, 1990; $\square$,

December 5, 1991. Temperature: see text.

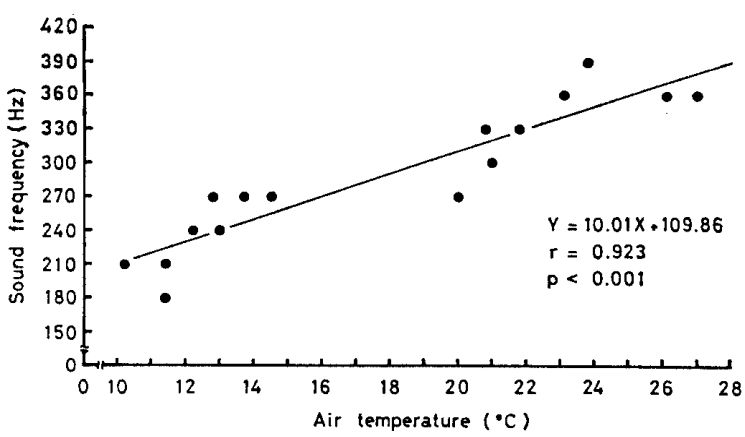

Fig. 4 Relationship between the sound frequency and the air temperature when the male catches were the highest each experimental day.

perature.

\section{Wingbeat frequency}

The wingbeat frequencies of male and female were measured in relation to both adult development after emergence and air temperature, and the results are shown in Figs. 5 and 6 . The wingbeat frequencies of both sexes were almost at constant levels during the experimental period except the male wingbeat frequencies tended to be low on the first day of emergence at 20 and $25^{\circ} \mathrm{C}$ (Fig. 5). The mean wingbeat frequencies of male ranged from 293.4 to $318.1 \mathrm{~Hz}$ at $10^{\circ} \mathrm{C}$, 382.1 to $405.3 \mathrm{~Hz}$ at $15^{\circ} \mathrm{C}, 460.6$ to $543.2 \mathrm{~Hz}$ at $20^{\circ} \mathrm{C}$ and 566.7 to $614.9 \mathrm{~Hz}$ at $25^{\circ} \mathrm{C}$. On the other hand, the mean wingbeat frequencies of female ranged from 212.9 to $240.0 \mathrm{~Hz}$ at $10^{\circ} \mathrm{C}, 274.0$ to $293.6 \mathrm{~Hz}$ at $15^{\circ} \mathrm{C}, 318.3$ to $358.8 \mathrm{~Hz}$ at $20^{\circ} \mathrm{C}$ and 371.0 to $382.9 \mathrm{~Hz}$ at $25^{\circ} \mathrm{C}$. When the mean frequencies of both

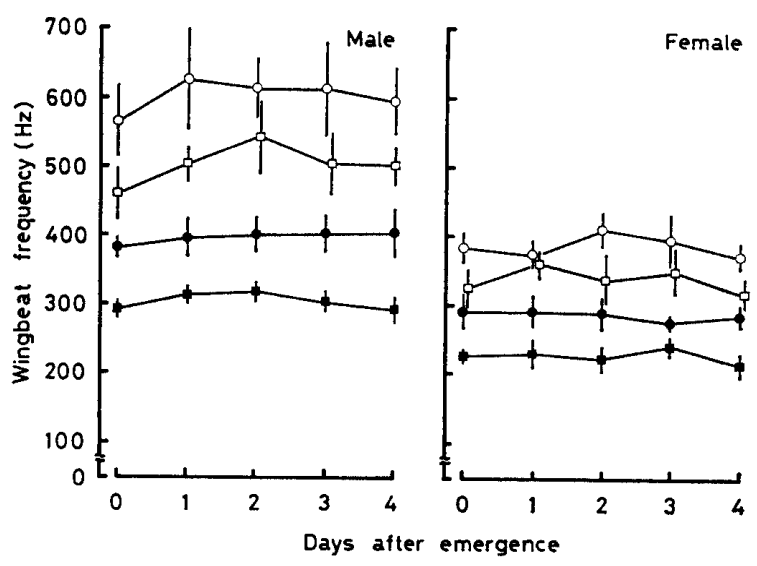

Fig. 5 Changes in wingbeat frequency of $C$. yoshimatsui after emergence at various air temperatures.

Vertical lines indicate standard deviations.

口, $10^{\circ} \mathrm{C} ; \bullet, 15^{\circ} \mathrm{C} ; \square, 20^{\circ} \mathrm{C} ; \bigcirc, 25^{\circ} \mathrm{C}$.

sexes were compared at the same age, the ratio of male to female ranged from 1.27:1 to $1.44: 1$ at $10^{\circ} \mathrm{C}, 1.31: 1$ to $1.47: 1$ at $15^{\circ} \mathrm{C}$, $1.41: 1$ to $1.60: 1$ at $20^{\circ} \mathrm{C}$ and $1.48: 1$ to $1.68: 1$ at $25^{\circ} \mathrm{C}$. Moreover, there was a good positive correlation between the air temperature and the wingbeat frequency of each adult day in both sexes (Fig. 6).

\section{Discussion}

Ogawa (1992) reported that a swarm of a chironomid midge, Rheotanytarsus kyotoensis was formed above the water surface of a river and was observed about noon to sunset. In the present study, however, the swarm of Chironomus yoshimatsui was formed close by the cherry tree as a swarm marker above the ground and toward evening or later, in the same study area. These results of observation indicate that the swarmforming conditions of $C$. yoshimatsui are different from those of $R$. kyotoensis. Moreover, the swarm of $C$. yoshimatsui consisted largely or entirely of males. This swarm feature is common to both the chironomid and the mosquito swarms (Downes, 1969; Marchand, 1984; Ikeshoji et al., 1985; Peloquin and Olson, 1985; Ogawa, 1992).

The swarming males were mainly caught by sound traps emitting sound frequencies between 180 and $390 \mathrm{~Hz}$, which are much 


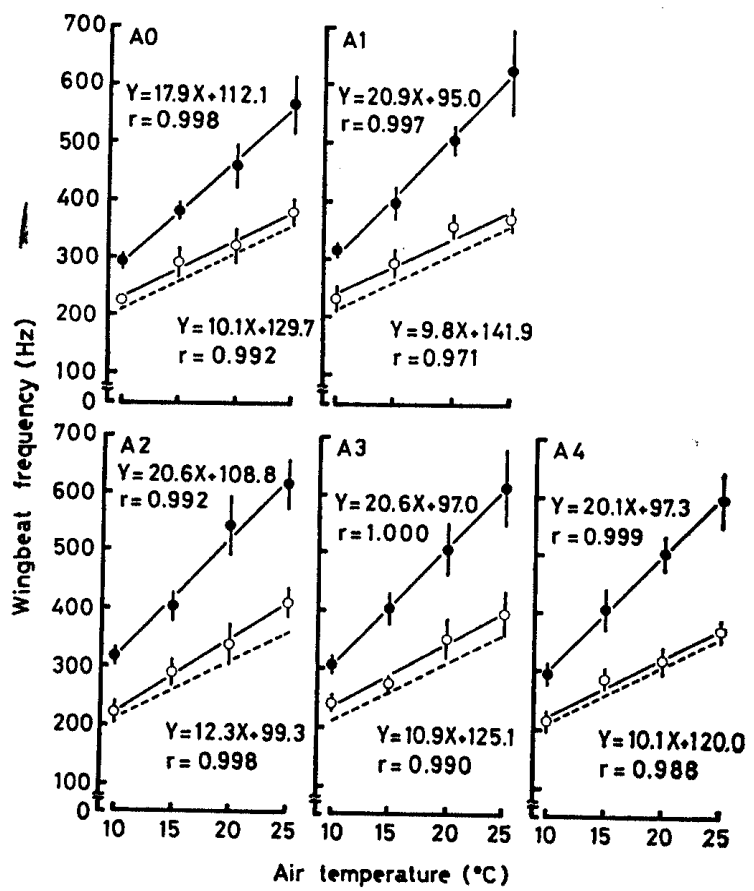

Fig. 6 Relationship between the wingbeat frequency and the air temperature each adult day after emergence.

Vertical lines indicate standard deviations. A0, the first day of emergence; A1, 1-dayold after emergence; A2, 2-day-old after emergence; A3, 3-day-old after emergence; A4, 4-day-old after emergence. $\bullet$, male; $O$, female; -..---, regression line of male acoustic response $Y=10.01 X+109.86$ (see Fig. 4).

the same frequencies as the female wingbeat frequencies, during the experimental period (ref. Fig. 5). However, the sound frequency of the highest male catch changed at the rate of $10 \mathrm{~Hz} /{ }^{\circ} \mathrm{C}$ which the regression line shows under the influence of ambient air temperature (Figs. 3 and 4). Moreover, the number of males caught decreased with a difference of only $30 \mathrm{~Hz}$ in frequency (Fig. 3 ). These results indicate that the swarming males respond to a fairly narrow range of sound frequency at an ambient air temperature. These acoustic responses of male $C$. yoshimatsui are quite similar to those of male R. kyotoensis (Ogawa, 1992).

The wingbeat frequencies of both sexes are almost independent of the adult age (Fig. 5). However, the wingbeat frequencies of both sexes are dependent on the ambient air temperature, and they rise linearly with rising air temperature (Fig. 6). The male wingbeat frequency was always higher than that of the female at the same air temperature each adult day (ref. Fig. 6). The ratio of the mean wingbeat frequency of male to female increased with rising air temperature. As shown in Fig. 6, the wingbeat frequencies change to $c a .20 \mathrm{~Hz} /{ }^{\circ} \mathrm{C}$ in male and $c a .10$ $\mathrm{Hz} /{ }^{\circ} \mathrm{C}$ in female, respectively, any adult day. These results indicate that increases in ambient air temperature produce more increases in the wingbeat frequency of male than that of female.

When the regression line of the female wingbeat frequency on the air temperature of each adult day is compared with that of the sound frequency of the highest male catch on the air temperature, there is no significant difference between the two regression lines in both regression coefficient and intercept at a $5 \%$ level ( $t$-test) (ref. Fig. 6). Moreover, the swarming males respond and orient to the sound trap emitting a sound frequency of $180-390 \mathrm{~Hz}$ which is much the same frequency as the wingbeat sound of conspecific female as mentioned above (ref. Fig. 5). Furthermore, swarming males of $C$. yoshimatsui remarkably respond to the sound frequency of $30-40 \mathrm{~Hz}$ higher than those of $R$. kyotoensis under the same ambient air temperature (Ogawa, 1992; Fig. 4). These facts indicate that swarming male of $C$. yoshimatsui has the hearing faculty to be accurately tuned to the wingbeat frequency of conspecific female which is variable with the ambient air temperature, and is able to respond and orient to the female. On the other hand, Ogawa (1992) reported on the acoustic response of male $R$. kyotoensis that swarming males were mainly caught by sound traps emitting sound frequencies between 180 and $300 \mathrm{~Hz}$ and the most attractive frequency changed to $c a .11 \mathrm{~Hz} /{ }^{\circ} \mathrm{C}$. Moreover, the swarming male of $R$. kyotoensis responded to a narrow range of sound frequency at an ambient air temperature. These results of acoustic response of male $R$. kyotoensis closely resemble those of male $C$. yoshimatsui. Therefore, it is inferred from this fact that male $R$. kyotoensis has the same hearing 
faculty as the male $C$. yoshimatsui.

In future, it is necessary to elucidate further the acoustic physiology and behaviour of adult of $C$. yoshimatsui for developing a new control method using acoustic response.

\section{Acknowledgements}

We thank Prof. T. Ikeshoji of the University of Tokyo for his advice and encouragement. We also thank the staff of the Laboratory of Applied Entomology of the University of Tokyo for making available their equipment for our use.

\section{REFERENGES}

Downes, J. A. (1969): The swarming and mating flight of Diptera. Annu. Rev. Entomol., 14: 271-298.

Freeman, P. (1950): A species of chironomid (Diptera) from the Sudan suspected of causing asthma. Proc. R. Entomol. Soc. Lond. (B), 19: 58-59.

Gad El Rab, M. O. (1980): Widespread IgEmediated hypersensitivity in the Sudan to the 'green nimitti' midge Cladotanytarsus lewisi (Diptera: Chironomidae). II. Identification of a major allergen. Clin. Exp. Immunol., 41: 389.

Igarashi, T., G. Murakami, Y. Adachi, M. Matsuo, Y. Saeki, T. Okada, K. Kawai, A. Kumagai and M. Sasa (1987): Common occurrence in Toyama of bronchial asthma induced by chironomid midges. Jpn. J. Exp. Med., 57: 1-9.

Ikeshoji, T. (1982): Use of sound for plant protection. Chem. Biol., 20: 687-694 (in Japanese).

Ikeshoji, T., M. Sakakibara and W. K. Reisen (1985): Removal sampling of male mosquitoes from field populations by sound-trapping. Jpn. J. Sanit. Zool., 36: 197-203.

Ito, K., T. Miyamoto, T. Shibuya, K. Kamei, K. Mano, T. Taniai and M. Sasa (1986): Skin test and radioallergosorbent test with extracts of larval and adult midges of Tokunagayusurika akamusi Tokunaga (Diptera: Chironomidae) in asthmatic patients of the metropolitan area of Tokyo. Ann. Allergy, 57: 199-204.

Kino, T., J. Chihara, K. Fukuda, Y. Sasaki, Y. Shogaki and S. Oshima (1987): Allergy to insects in Japan. J. Allergy Clin. Immunol., 79 : 857-866.

Marchand, R. P. (1984): Field observations on swarming and mating in Anopheles gambiae mosquitoes in Tanzania. Neth. J. Zool., 34: 367-387.

Murakami, G., T. Igarashi, Y. Saeki, Y. Adachi, M. Matsuno, T. Okada, K. Kawai, A. Kumagai and M. Sasa (1986): Clinical studies of bronchial asthma induced by chironomid midges. Jpn. J. Allerg., 35: 393-401 (in Japanese with English summary).

Ogawa, K. (1988): Field study on acoustic trapping of Mansonia (Diptera: Culicidae) in $\mathrm{Ma}-$ laysia. I. Mass-trapping of males by a cylindrical sound trap. Appl. Entomol. Zool., 23: 265-272.

Ogawa, K. (1992): Field trapping of male midges Rheotanytarsus kyotoensis (Diptera: Chironomidae) by sounds. Jpn. J. Sanit. Zool., 43: 77-80.

Peloquin, J. J. and J. K. Olson (1985) : Observations on male swarms of Psorophora columbiae in Texas ricelands. J. Am. Mosq. Control Assoc., 1: $482-488$.

$$
\begin{gathered}
\text { 摘 要 } \\
\text { セスジュスリカ Chironomus yoshimatsui } \\
\text { における雄の音響応答と雌の } \\
\text { 羽音周波数との関係 }
\end{gathered}
$$

群飛しているセスジュスリカの雄の音響応答を音響 トラップを用いて野外で調べるとともに，雌雄の羽音

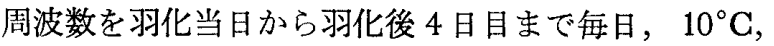
$15^{\circ} \mathrm{C}, 20^{\circ} \mathrm{C}$ 扝よび $25^{\circ} \mathrm{C}$ の各温度条件下で測定し た. 群飛は成虫の発生源の河川際の桜の木の幹横およ び枝下に, 地上 $0.5 \mathrm{~m}$ から $5 \mathrm{~m}$ 以上の高さに形成さ れた. 群飛は平均 $98.0 \%$ が雄で構成されていた. 雄 は主に周波数 $180 \mathrm{~Hz}$ から $390 \mathrm{~Hz}$ の音響に対して応 答し，トラップに誘引・捕獲された．しかし，一定の 気温条件下では, 雄が顕著に応答する音響周波数の範 囲がかなり狭いことも明らかとなった。この雄の音響 応答において，捕獲に最適な音響周波数と気温との間 にきわめて高い正の相関が認められ，音響周波数の変 動は $10 \mathrm{~Hz} /{ }^{\circ} \mathrm{C}$ であった。䧳雄の羽音周波数は同一気 温条件下で, 羽化当日から羽化後 4 日目までほぼ一定 であった. 雄の羽音周波数は同日齢の雌より常に高く て，1.27倍から 1.68 倍であった。いずれの日齢にお いても，羽音周波数と気温との間にきわめて高い正の 相関が雌雄ともに認められた，その羽音周波数の変動 は雄で 18〜 $21 \mathrm{~Hz} /{ }^{\circ} \mathrm{C}$, 雌で $10 \sim 12 \mathrm{~Hz} /{ }^{\circ} \mathrm{C}$ であっ た. さらに，気温に対する雄の音響応答の回帰直線と 気温に対する雌の羽音周波数の回帰直線はいずれの日 龄においても一致した。これらのことから，セスジュ スリカの雄は気温の影響を受けて変動する雌の羽音周 波数に的確に同調し，忘答できる聴覚能力を有してい ることが明らかとなった。 